\title{
Obituary
}

\section{Sir Ernst Chain, FRS}

Rheumatology has lost one of its greatest contributors, although few would recognise him under this description. Alexander Fleming discovered penicillin in 1929 but failed to realise its potential importance or exploit its capacity to cure human disease. Nine years later Ernst Chain, a refugee from Hitler's Germany who had arrived in Britain in 1933 at the age of 27 , came across his paper and attempted to reproduce his results. It was no accident that Chain was working in this field, as he had already been studying lysozyme, an enzyme capable of destroying bacteria. Chain eventually concentrated the active substance produced by the mould penicillium and showed that it prevented death in mice injected with a fatal dose of streptococci. This simple experiment, which Fleming might have done but did not, eventually led to the virtual elimination from our rheumatology clinics of infective arthritis caused by penicillin-sensitive organisms-gono- coccal, streptococcal, syphilitic, and many others. Few would doubt that it also delivered the coup de grace to rheumatic fever (although this had been declining in incidence before the antibiotic era) and? that Chain's work saved the lives of many rheumatic children and prevented much chronic rheumaticu heart disease. With Fleming and Florey he waş awarded the Nobel prize for this work.

Chain was also the first to isolate and characterise D-penicillamine, which was used to prevent the visceral, bone, and joint complications of Wilson'sdisease and was subsequently established as an effective remittive drug in chronic rheumatoio arthritis.

In view of his services to rheumatology Sir Ernst Chain was made an honorary member of the Heber $=$ den Society in 1973.

A ST. J. DIxक्ष

\section{Change in style of references}

In accordance with the Vancouver agreement many medical journals are to standardise the instructions they issue to authors on the preparation of articles. References will be cited by the numerical system already familiar in many journals, including the British Medical Journal. A paper (or book) cited in the text is referred to there by a superscript number. In the list of references the papers (or books) appear in the numerical order in which they are first cited in the text, not in alphabetical order by authors' names. For convenience in preparing the typescript the reference number may be typed between parentheses on the line, not superscript. The titles of journals will be abbreviated in accordance with the style of Index Medicus. In the typescript they should either be abbreviated in that style or given in full. This journal will change to the numerical system from the first issue of 1980. Authors submitting papers are asked to adopt now in order to facilitate editing. Three examples follow? ${ }^{1}$ Green A B, Brown C D, Grey E F. A new method of measuring the blood glucose. Ann Rheum Dis 1980; 64: 27-32.

${ }^{2}$ Green A B, Brown C D. Textbook of Medicine. Londonct Silver Books, 1980.

${ }^{3}$ Grey E F. Diseases of the pancreas. In: Green A Brown C D, eds. Textbook of Medicine. London Silver Books, 1980; 349-362.

Copies of the Vancouver agreement $(50 \mathrm{p}$, post free) are obtainable from the Publishing Manager, British Medical Journal, BMA House, Tavistock Square London WC1H 9JR. 